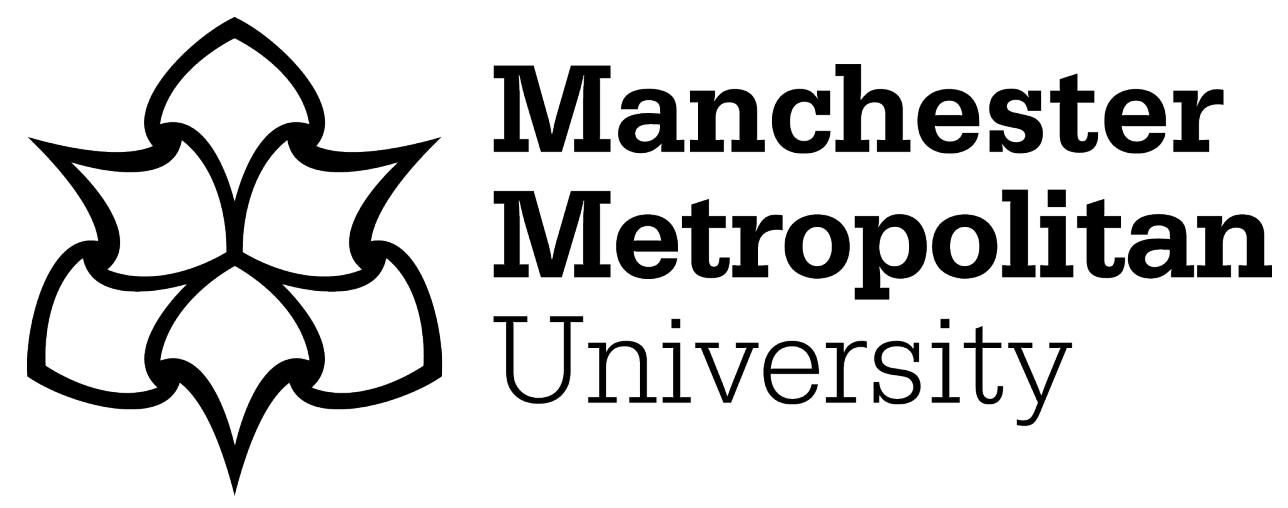

Dixon, S ORCID logoORCID: https://orcid.org/0000-0001-7444-0445 (2019) Ceramics, narrative and commemoration. Craft Research, 10 (1). pp. 121131. ISSN 2040-4689

Downloaded from: https://e-space.mmu.ac.uk/623498/

Version: Accepted Version

Publisher: Intellect

DOI: https://doi.org/10.1386/crre.10.1.121_1

Please cite the published version 


\section{THE PORTRAIT SECTION}

\section{STEPHEN DIXON \\ Manchester Metropolitan University}

Ceramics, narrative and commemoration.

\section{Introduction}

My career as a maker is defined by a commitment to politically engaged practice, and a belief in the power of craft to inform the public imagination and to make a difference. My research embraces the narrative and decorative traditions of figurative ceramics, and brings this rich visual vocabulary to bear on contemporary issues and contemporary experience. In recent years, practice-led projects have focused on the commemorative nature of ceramics, resulting in an increasing engagement with the material resonance of historic and archival objects. This period has seen the development of new initiatives working with museums, archives and the public to explore memory and monument-making, particularly in connection with the centenary of World War 1.

\section{Shifting practice: from studio to site.}

I entered academia in 1998, as a Research Fellow at Manchester Metropolitan University, in the Department of Contemporary Arts at MMU Cheshire, then under the leadership of Professor Robin Nelson (Nelson 2013). Prior to that I had established something of a reputation as a 'political' ceramicist, both in the UK and in the USA ${ }^{1}$, and had developed a portfolio practice which included studio ceramics, commissioned work, and part-time lecturing. My initial research brief at MMU was to develop innovative printing processes across the material areas of the Contemporary Crafts programme (textiles, ceramics wood and metal) with a particular focus on ceramics. One early outcome of the fellowship was the development of a water-based ceramic transfer printing process, using silk-screen-printing and traditional decal paper in conjunction with an acrylic-based ceramic ink. This technical process became the cornerstone of an extensive investigation of visual narrative and the ceramic surface, and its application as political commentary. This culminated in 21 countries at the Imperial War Museum North, an installation of 21 plates which chronicled the buildup to the War on Iraq in 2003.

Figure 1: Stephen Dixon. (2003) 21 Countries. (C) Stephen Dixon. Photographer Joel Fildes. Figure 2: Stephen Dixon. (2006) Beyond the Seas (detail). (C) Stephen Dixon. Photographer Tony Richards.

In the early years of the fellowship I enjoyed a high level of research autonomy, and a freedom to explore new research directions ${ }^{2}$. In 2006 I travelled to Australia on an AHRC travel grant, as part of the Here and There (HAT) Project ${ }^{3}$, to investigate the effects of geographical dislocation on the creation of cultural artefacts. This experience provoked a shift away from the ceramic vessel as a vehicle for narrative, towards intervention and installation works that exploited the embodied narratives and material resonance of 'found' objects and artefacts. Building on this new conceptual vocabulary, Monopoly, commissioned for the first British Ceramics Biennial in 2009, re-purposed 30,000 hand-made bone china 
flowers, expanding the form of the battleship token from the property developing board game, as a site-specific memorial to the banking crisis of 2008 and its economic and industrial consequences in the potteries.

Figure 3: Stephen Dixon. (2009) Monopoly. (C) Stephen Dixon. Photographer Joel Fildes. Figure 4: Stephen Dixon. (2013) Restoration Series, Carl Von Ossietzky . (C) Stephen Dixon. Photographer Tony Richards.

My involvement in the British Ceramics Biennial was closely followed by a 6-month artists residency in the newly created ceramics studio in the refurbished ceramics galleries at the V\&A, South Kensington, London where I embarked on a new body of work exploring iconic political portraiture in ceramics. The Restoration Series (2011-13) adopted the convention of the commemorative portrait bust, to explore issues of fundamental human rights and freedom of conscience. The portraits were based on three Nobel Peace Prize winners, Carl Von Ossietzky (awarded 1935) Aung San Suu Kyi (awarded 1989) and Lui Xiaobo (awarded 2010) and were linked by the fact that, as prisoners of conscience at the time of their award, none of the three were able to receive their prize from the Nobel organisation.

\section{Memory and monument-making.}

A cluster of related research projects Resonance (2015), Resonate (2015) and The Lost Boys (2016) have examined commemoration and the mnemonic resonance of archives and objects, in the context of the centenary of World War 1. Another project, Passchendaele: mud and memory (2017) focused specifically on the materiality of the conflict, exploiting the evocative materiality of terracotta clay sourced from the battlefields of the Western Front. Collectively, these projects aimed to employ the emotive agency of collections, archives and excavated objects, to engage cultural memory and commemorate specific aspects of the First World War. Additionally, each of these projects featured a significant element of direct public participation in the resulting exhibitions, and a methodology for co-creation was tested over the course of the four projects.

Resonance was a touring exhibition commissioned by a consortium of seven Staffordshire museums, including the Potteries Museum and Art Gallery and the Wedgwood Museum. I worked alongside photographer and film-maker Johnny Magee, to develop an exhibition of new work made in response to the museums' First World War archives and collections, which evolved and expanded as the tour progressed.

I was excited to discover Crested China, a genre of ceramics previously unknown to me, in several of the Staffordshire collections. This was a form of popular commemorative ware, collected by British holidaymakers on their seaside excursions from the 1880's to the 1930's. Crested China was in its heyday during World War 1; it documented and commemorated the events of the war, depicting military figures and the hardware and machinery of war, taking a patriotic and often propagandist line. My intention with The Beautiful Game (2014) was to extend the genre, by adding to the range of Crested China subjects, but taking a more critical perspective. The timing of the first exhibition was perfect 
to look at the events of the Christmas Truce of 1914, an event described by Arthur Conan Doyle as "One human episode amid all the atrocities that have stained the memory of the war". I modelled and cast a British footballer-soldier in the genre of crested china, replicating the modelling style of the originals, followed by a model of a German footballersoldier and then two goalkeepers, resulting in two complete football teams. Importantly, each figure was named after a soldier who had both witnessed and written about the events of the Christmas Truce, and each carried the badge of his regiment as a crest. In this way, the work acted as a literal and physical testimony to the veracity of the event.

We tested an embryonic participation model, inviting the public to take part in workshops to design and produce digitally printed ${ }^{4}$ ceramic artefacts - facsimile World War 1 tankards to commemorate a known relative who took part in World War 1. These tankards collectively formed one of the central artworks in the exhibition, Column, which became more 'populated' as each new workshop took place; a metaphor for the increased involvement of the population as the war progressed.

Figure 5: Stephen Dixon. (2014) The Beautiful Game. (C) Stephen Dixon. Photographer Tony Richards.

Figure 6: Stephen Dixon. (2015) Column (detail). (C) Stephen Dixon. Photographer Tony Richards

Our involvement with Resonance led to further invitations to take part in commemorative projects. The central focus of Resonate was a monumental clay head, made for the British Ceramics Biennial in 2015, which used two tons of Staffordshire Etruria Marl clay to commemorate the 5,406 soldiers of the North Staffordshire Regiment killed in World War 1. It was loosely based on the head of the goddess Nike, from William McMillan's Allied Victory Medal of 1919. The head was only one element of the installation, it also featured an eerie and disturbing sound piece by Johnny Magee, based on the Jerome Kern classic They didn't believe me, and an element of mass audience participation; visitors were invited to attach white bone china flowers to the scaffolding structure, and also to add tags featuring their own hand-written thoughts, tributes and memories.

Figure 7: Stephen Dixon. (2015) Resonate. (C Stephen Dixon. Photographer Joel Fildes.

The Lost Boys was an AHRC funded Public Engagement Project, developed in partnership with the Clay Foundation, as part of the Voices of War and Peace project. It examined the issue of boy soldiers - an estimated 250,000 underage soldiers between the ages of 14 and 18 served in the British Army in WW1. We worked with young volunteers aged 14 to 18 , initially researching the British Army records and the death notices on the local newspaper database, at Staffordshire County Records Office. These local soldiers' stories became the narrative for a series of ceramic pieces made by the volunteers, including an installation of 32 ceramic plates, made using laser printed decals and digital transfer prints.

Figure 8: Stephen Dixon. (2016) The Lost Boys. (C) Stephen Dixon. Photographer Tony Richards.

\section{Mud and materiality.}


Another commission followed in 2017, this time for a commemorative exhibition at the National Memorial Arboretum, on the centenary of Passchendaele. This battle is remembered as one of the most cruel and futile of campaigns, even by the terrible standards of World War 1, fought in the cloying mud of western Flanders, where an estimated 150,000 soldiers from both sides perished in the mud and rain. The centerpiece of Passchendaele: Mud and Memory was a large portrait sculpture, made from terracotta clay sourced from the Wienerberger quarry and brickworks, located on the battlefield site at Zonnebeke. The portrait is an 'everyman', an assemblage of features from soldiers of the many nations who fought and died at Passchendaele, and is based on photographs of individual soldiers sourced in the Passchendaele Memorial Museum archives. Unlike the Resonate head (which was unfired and left to dry, shrink and crack apart during the BCB exhibition) this portrait was fired in its individual sections and assembled post-firing.

Three display cases in the exhibition represented each of the main combatant nations (the United Kingdom, France and Germany) and examined material resonance from a curatorial perspective. Each case contained excavated battlefield artefacts and items of popular culture, from the collections of the Passchendaele Memorial Museum and from my own collection. These included pianola rolls, romantic song postcards and objects which bore poignant, personal associations; a pair of glasses, a penknife, a harmonica, a cigarette lighter, a wristwatch, a pocket shrine. The similarity of the objects in these installations emphasised the commonality of experience shared by soldiers on both sides of the conflict. Passchendaele: Mud and Memory extended and refined the public participation model developed for Resonance, working with museum visitors and volunteers to engage with the materiality of the WW1 battlefield, drawing and printing the excavated artefacts onto facsimile Navy and Army Canteen Board (NACB) plates ${ }^{5}$, as a major installation of 108 plates within the exhibition.

Figure 9: Stephen Dixon. (2017) Passchendaele: Mud and Memory. (C) Stephen Dixon. Photographer Tony Richards.

Figure 10: Unknown manufacturer, collection Stephen Dixon. (c.1914) Pocket Shrine. (c) Stephen Dixon. Photographer Tony Richards.

The objects and artworks in Passchendaele: Mud and Memory exploited the significant and specific congruences of time, place and material to create a physical encounter with the excavated personal artefacts of soldiers from both sides of the conflict. My adoption of the methodological strategies of congruence (the use of resonant and symbolic objects as the components of visual narrative) and encounter owes much to the commemorative artworks of Cornelia Parker and Jeremy Deller; War Rooms (Parker 2015) and We're here because we're here (Deller 2016).

As the World War 1 centenary concludes, and with Passchendaele: Mud and Memory about to open in Belgium ${ }^{6}$, this seems an appropriate time to reflect on the opportunities and the challenges these recent projects have brought to my practice. Scale is perhaps the obvious place to start. The creative freedom afforded by the British Ceramics Biennial gave me the opportunity to develop Resonate on a huge scale ${ }^{7}$, though my ambition to fire and reassemble the now-fragmented sections of the sculpture have yet to be realized. There is a legacy to the project though, in the form of a video by Johnny Magee Things Just Happen 
Anyway ${ }^{8}$, and this new relationship with film has added a new dimension to my practice. The experience of making (or rather un-making) Resonate led me to design the Passchendaele portrait on a more practical scale, up-sizing the modular structure developed for the Restoration Series at the V\&A. The significant innovation within the Passchendaele project was the use of congruent evocative and emotive materials - the clay and excavated objects from the battlefield, as a crucial element of the narrative.

The most challenging aspect to all of my World War 1 projects was in dealing with public sensitivity around remembrance and commemoration; how to adopt a critical perspective on war and conflict, while at the same time retaining a sense of reverence to the loss and sacrifice of the individuals that were affected. I struggled with this at first, but the public response to Resonance (particularly the sentiment embodied in The Beautiful Game) gave me the confidence to embed an underlying anti-war ethos within the work. Lest we forget, this was the war that initiated and rehearsed all of the subsequent horrors of the twentieth century: genocide, chemical warfare, the aerial bombardment of civilians and submarine warfare, to name only a few.

\section{References.}

Deller, J. (2016) We're here because we're here, at railway stations, shopping centres and other places across the UK, 1 July.

Nelson, R. (2013) Practice as Research in the Arts, Palgrave Macmillan, UK.

Parker, C. (2015) War Rooms, at Whitworth Art Gallery, 14 February - 31 May.

\section{Contributor details}

Stephen Dixon is Professor of Contemporary Crafts at Manchester School of Art. He studied Fine Art at Newcastle University and Ceramics at the Royal College of Art, graduating in 1986. His work features in numerous public and private collections, including the Museum of Arts \& Design, New York; the Victoria \& Albert Museum; the British Council; the Crafts Council; the Royal Museum of Scotland and the Fine Arts Museums of San Francisco. He was a Trustee of the Crafts Council from 2009 to 2013, and is a member of the Art and Design sub-panel for REF 2021.

Contact: Room 1.08, Righton Building, Manchester Metropolitan University, All Saints, Manchester M15 6BH

E-mail: s.dixon@mmu.ac.uk

\footnotetext{
${ }^{1}$ Pro-Art Gallery, St. Louis, 1992; Garth Clark Gallery, New York 1995; Nancy Margolis Gallery, New York, 1998.

2 The MMU fellowship continued until 2007, when I was awarded a Professorship.
} 
${ }^{3}$ The Here and There (HAT) Project was an international crafts research exchange project, initiated by A Fine Line (Barney Hare Duke and Jeremy Theophilus).

${ }^{4}$ The original drawings were scanned and digitally printed as ceramic transfers using a DCS (Digital Ceramic Systems) printer.

${ }^{5}$ These drawings were printed onto Fotocal transfer paper using a B/W laser photocopier.

${ }^{6}$ Memorial Museum Passchendaele 1917, February to May 2019.

${ }^{7}$ Resonate was 3 metres high by 2 metres wide, and was made using 2 tons of Etruria marl.

${ }^{8}$ https://vimeo.com/295015787 